喉 頭 悪性リンパ腫 例

瓦井 博子1) ・渡辺 周一2) $\cdot$ 山本 幸代2)

福島 邦博2) ・吉野 正 ${ }^{3)}$ 岡田 聡子4)

\title{
A Case of Malignant Lymphoma of the Larynx
}

\author{
Hiroko Kawarai \\ (Okayama Rosai Hospital) \\ Shuichi Watanabe, Sachiyo Yamamoto, Kunihiro Fukushima and Tadashi Yoshino \\ (Okayama University Medical School) \\ Satoko Okada \\ (Tamano City Hospital)

\begin{abstract}
A case of malignant lymphoma of the larynx in a 55-year-old male is reported with a review of the literature. Patient's chief complaint was an abnormal feeling in his larynx. Laryngoscopy revealed a tumor in the right aryepiglottic fold. Biopsy showed B cell type non-Hodgkin's malignant lymphoma. The clinical stage of this patient was IE. He was treated with chemotherapy (CHOP) and radiation therapy (30 Gy). The tumor was well controlled, and no recurrence was noted one year and eight months after discharge.
\end{abstract}

Key words : malignant lymphoma, larynx, chemotherapy

はじめに

喉頭悪性リンパ腫は，全喉頭覀性腫瘍の $1 \%$ 未満とい われる，非常に稀な疾患である，今回我々は，喉頭披裂 部が原発と思われる喉頭悪性リンパ腫を経験したので, 症例を呈示するとともに，若干の文献的考察を加えて報 告する.

\section{症例}

症例 : 55歳, 男性.

主訴：咽喉頭異常感.

家族歴 : 特記すべき事なし。

既往歴 : 特記すべき事なし。

現病歷: 平成 5 年 7 月上旬より咽喉頭異常感が出現し, 近医耳鼻咽喉科を受診する。喉頭右披裂部の腫瘍を指摘
され，直達鏡にて生検を施行されるも病理組織学的には， atypical lymphoid hyperplasia と, 確定診断には至らず, 8 月に当科紹介受診となる。 また，全経過を通じて，嗄 声, 呼吸困難, 嚥下困難などの自覚症状は認められなか った。

初診時所見：当科初診時には，喉頭右披裂部に表面平 滑な白色の腫瘍を認めた。腫瘍は正中を超えており，左 披裂部孔若干の腫脹を認めた。 また, 声帯に軽度の発赤 を認めたが，可動性は良好であった(図 1)。その他，ワ ルダイエル輪を含む他の耳鼻咽喉所見に異常はなく, 頸 部リンパ節も触知しなかった。

入院後の経過 : 悪性リンパ腫を疑い, 診断確定のため 十分な大きさの組織片を採取する目的にて，9月20日気 管切開の上，全身麻酔下に喉頭微細手術を施行した。 


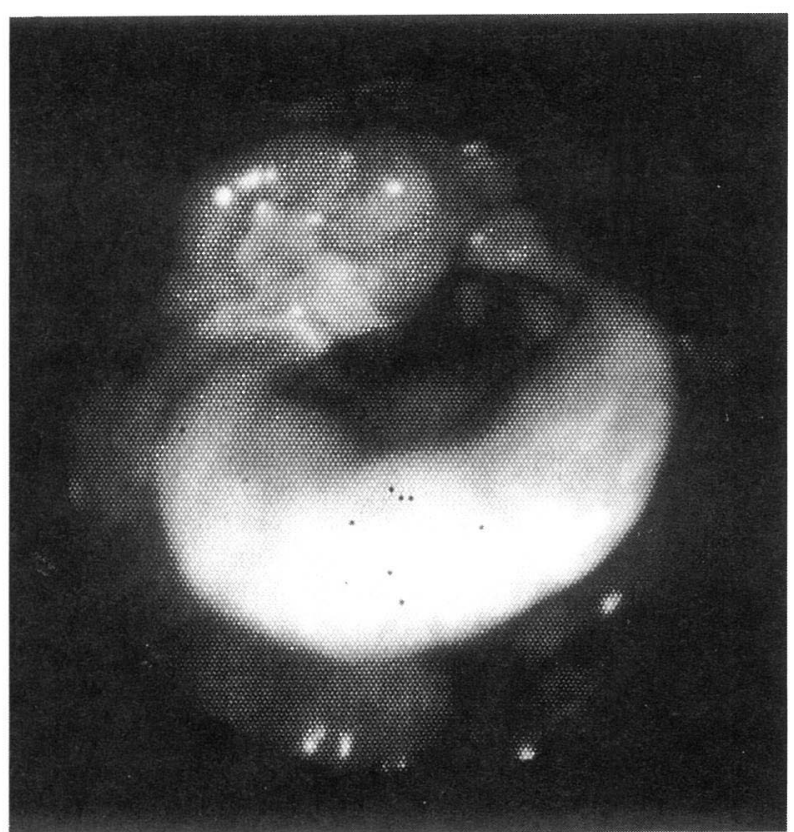

図 1 ファイバー所見 喉頭右披裂部に表面平滑な白色の腫瘍を認める.

病理組織学的検査の結果は non Hodgkin lymphoma, Working Formulation で diffuse lymphoma, large cell, immunoblastic で，免疫染色は CD45 と CD20 が陽性， CD45RO と CD43 が陰性でB細胞性であった(図 2).

臨床検査所見：末梢血液像に特に異常を認めず, また,

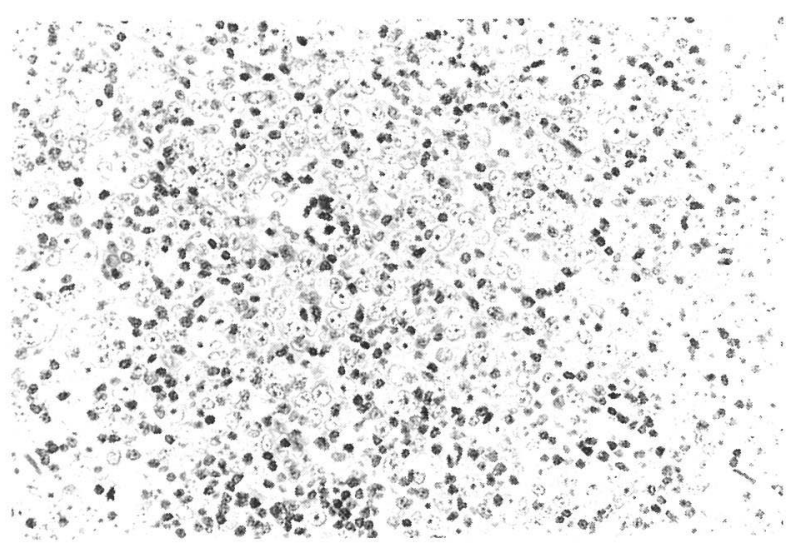

図 2 H-E 染色 $(\times 200)$

採取された材料の一部にリンパ腫組織が認められた。リ ンパ腫細胞は 1 〜数個の明瞭な核小体を伴ら大型類円核 を有して拈り，immunoblasticな細胞が目立った。
胸部, 腹部 CT, ガリウムシンチグラフィー, 骨䯣検査, 上部消化管造影に拈いて, 喉頭以外の病変部を認めず, 喉頭に限局した悪性リンパ腫 stage IE と診断した.

治療として，サイクロフォスファマイド，アドリアマ イシン，ビンクリスチン，プレドニゾロンを使用したい わゆる CHOP 療法を4 クール施行し, その後, 喉頭括 よび鎖骨上窩に前後対向 2 門法にてライナック $30 \mathrm{~Gy}$ を照射した。治療に対する著明な副作用なく, 視診上腫 瘍は消失した。平成 6 年 3 月退院し, 現在外来にて経過 観察中である.

\section{考察}

喉頭の非上皮性腫瘍は極めて稀で，全喉頭腫瘍の $2 \%$ 未満である。さらに同部位に拈ける非上皮性の悪性腫瘍 は1\%未満であり1)，喉頭悪性リンパ腫は本邦では1942 年の岡部 2$)$ の報告以来, 自験例を含めて54例の報告を認 めるのみである，発症年齢は，40～60歳が中心だが，喉 頭癌に比べ, 若年者に発症する割合が多いといら特徵が ある、

性別をみると，性差がみられないとするもの ${ }^{324)}$, 女 性に多いとするもの5)などがあり，一定の見解を認めな い、いずれにしても, 喉頭癌が男性に圧倒的に多いこと に比べ，喉頭悪性リンパ腫で男性の比率が比較的低いの は特徴的といえる。

好発部位については声門上が最も多く, 今までの文献 報告例の検索から, Gregor ${ }^{3)}$ は80\%, Anderson ら ${ }^{1)}$ は $70 \%$ ，堤ら 6 は $66.7 \%$ が声門上より発生すると述べてい る.

主訴は, 大多数が嗄声で, 次に, 呼吸困難, 狭窄感な どの喉頭異物感，與下困難などが報告されている．疼痛 を訴えた症例は検索し得た範囲では報告が認められなか ったが，これは，潰瘍形成が稀なためと考觉られる。

肉眼的所見については, 表面平滑なびまん性の腫脹で, 粘膜に被われ, 非潰瘍性, 色調は蒼白あるいは赤みをお びて扣り，炎症性腫脹と鑑別しにくいことが特徵である。 今回の症例について考察すると, 55歳男性, 声門上の 発生と, かなり典型的な症例と考えられる。また, 声帯 の可動性が良好だったため, 嗄声をさたさず咽喉頭異常 感といら主訴で受診したと考えられた。

診断は, 病理組織学的検査によるが, 他の部位に比べ 十分な大きさの組織片を採取することが困難なため，1 回目の生検で診断が確定しない症例が多く, 悪性リンパ 
腫を疑った場合，できるだけ挫减をきたさず，より大き な切片を採取することが，早期猃断につながると考えら れる、レーザーメスを使用することで，上り大きく深部 より鋭利に組織採取を行った報告6) もある. 今回我々が 経験した症例についても，2 回目の生検で診断が確定し ており,そのため, 視診で喉頭に表面平滑でびまん性の 腫脹を認めた場合，悪性リンパ腫も念頭におき，十分な 大きさの組織片を採取する必要があると思われる.

病理学的特徵をみてみると, 使用される分類の変遷に ともなって, 症例間の詳細な比較は困難であるが, 細網 肉腫と診断されたものが多く,び慢性大細胞型や混合細 胞型が主体であることをらかがわせる．1980年以降の報
告で我々が検索し得た範囲では, 滤胞性リンパ腫の報告 はみられず，あっても極めて稀と考号れる。この点は 節性のリンパ腫と異なる点である. 本症例では核小体が 明瞭な immunoblastic な細胞が目立つため, 現在広く 使用されているWorking Formulation (WF) に従い large cell, immunoblastic と診断した. Immunoblastic を主体とするリンパ腫はWF が提唱された時点では予 後が悪いと考兄られたため高悪性度に分類されたが，現 在では他の大細胞型と同様に扱われている. 国際的な新 しい分類, いわゆる REAL 分類でも, 大型細胞主体の B リンパ腫を diffuse large B-cell lymphoma として一括 している7).

表 11980 年以降の本邦悪性リンパ腫症例一覧

\begin{tabular}{|c|c|c|c|c|c|c|}
\hline 報告者 & 年齢 & 性別 & 原 & 免疫組織 & & 帰 \\
\hline 古謝 $5^{8)}$ & 62 & 女 & 仮声帯, 披裂喉頭蓋 & 不詳 & 生存 & （不詳） \\
\hline 大野 ${ }^{9)}$ & 39 & 女 & 左声带, 声門下腔 & lymphocytic & 生存 & （不詳） \\
\hline 都川ら & 66 & 女 & 仮声帯, 披裂部, 軟口蓋 & lymphocytic & 生存 & （不詳） \\
\hline 卜部ら5) & 39 & 女 & 右仮声帯 & diffuse lymphocytic & 生存 & ( 6 力月) \\
\hline 富樫ら & 53 & 男 & 左仮声帯 & diffuse medium & 生存 & ( 5 力月) \\
\hline 堤内ら ${ }^{12)}$ & 73 & 女 & 声門下 & diffuse lymphocytic & 生存 & （ 1 年） \\
\hline 大八木ら ${ }^{13)}$ & 53 & 女 & 声門下腔 & diffuse small & 生存 & （不詳） \\
\hline 大八木ら ${ }^{13)}$ & 53 & 男 & 喉頭蓋 & diffuse mixed & 生存 & (不詳) \\
\hline 堤 $5^{6)}$ & 56 & 男 & 右仮声帯 & diffuse small & 生存 & （1.5年） \\
\hline 稲光ら ${ }^{14)}$ & 28 & 女 & 左仮声帯, 声門下 & $\mathrm{T}$ cell & 他因死 & ( 2 力月) \\
\hline 奥村 ${ }^{15)}$ & 19 & 男 & 左披裂部 & diffuse small & 生存 & (不詳) \\
\hline 太根 $5^{16)}$ & 81 & 男 & 右仮声帯 & 不詳 ～～～～～ & 生存 & （不詳） \\
\hline 小倉ら ${ }^{17)}$ & 63 & 女 & 左声帯 & diffuse medium, $\mathrm{B}$ & 生存 & （不詳） \\
\hline 増田ら ${ }^{18)}$ & 70 & 女 & 声門下 & diffuse large & 生存 & （ 3 年） \\
\hline 加島 $5^{19)}$ & 77 & 男 & 左仮声帯 & diffuse large & 生存 & （不詳） \\
\hline 石山 ${ }^{20)}$ & 55 & 男 & 右仮声带 & diffuse, $\mathrm{T}$ & 生存 & ( 2 力月) \\
\hline 松田 $5^{21)}$ & 65 & 女 & 披裂部 & small & 不明 & \\
\hline 酒井ら ${ }^{22)}$ & 10 & 女 & 右仮声帯 ～～～～ & diffuse medium & 生存 & ( 1 年 1 力月) \\
\hline 青地ら ${ }^{23)}$ & 46 & 女 & 左仮声帯, 右舌根部 & diffuse mixed, B & 生存 & （3.5年） \\
\hline 青地ら 23) & 30 & 女 & 右仮声帯 & diffuse medium, $\mathrm{T}$ & 生存 & （1.5年） \\
\hline 宇野 5 & 72 & 女 & 左仮声帯 & mixed & 死亡 & （ 2 年） \\
\hline 仁村ら ${ }^{25)}$ & 72 & 男 & & diffuse mixed, $T$ & 死亡 & ( 5 カ月) \\
\hline 山形ら ${ }^{26)}$ & 82 & 女 & 右披裂部 & diffuse medium & 生存 & (不詳) \\
\hline \multirow[t]{5}{*}{ 永橋ら 27$)$} & 107 & & & & & \\
\hline & 44 & 男 1 & 仮声帯 2 & diffuse small cleaved 3 & \multirow{4}{*}{\multicolumn{2}{|c|}{$\begin{array}{l}\text { 生存 } 2 \text { (不詳) } \\
\text { 死亡 } 2 \text { (不詳) }\end{array}$}} \\
\hline & 45 & 女 3 & 声門下 1 & diffuse mixed 1 & & \\
\hline & $46-$ & & 仮声帯，喉頭室 1 & 1 例は B cell & & \\
\hline & （順不同， & 4 例） & & & & \\
\hline 寺田ら 28$)$ & 77 & 女 & 左声帯 & diffuse, $B$ & 生存 & （1.5年） \\
\hline 菅家 ${ }^{29)}$ & 44 & 女 & 声門下腔 & diffuse medium, $\mathrm{B}$ & 不明 & \\
\hline 平尾ら ${ }^{30)}$ & 15 & 男 & 声門下 & diffuse large, $B$ & 生存 & （3.5年） \\
\hline 自験例 & 55 & 男 & 右披裂部 & diffuse large, immunoblastic, $\mathrm{B}$ & 生存 & ( 1 年 8 力月) \\
\hline
\end{tabular}


我々の症例は $\mathrm{CD} 20$ 陽性でB 細胞性であることが判明 したが，1980年以降の 31 例の既報告で T， B 細胞型を記 載しているものは11例にとどまる(表 1 ( )5668) 30)。この 万ち T細胞性が 4 例, B 細胞性が 7 例であり, この部位 にはT細胞性 B 細胞性リンパ腫の両者ともに発生するこ とがわかるが，その表面形質の差がどのような臨床上の 差異を示すかは現在のところ判然としない.今後の臨床 蓄積が待たれるところである。

治療については，一般的に悪性リンパ腫の局所制御率 は，化学療法より放射線治療の方が高いと考兄られてい る. しかし, non Hodgkin lymphoma は，非連続的な進 展様式をとることが多く，放射線治療のみでは照射野外 へ病巣を残す可能性が高いという報告18202022)23311) が多く みられる.そのため, 近年ではstage I に対しても， 化学療法と放射線治療の両者の併用療法が認められつつ あり，予後の向上のためにも必要ではないかと考えられ る. 今回の症例も, 喉頭以外への浸潤を早期に予防する 目的にて化学療法を先行させ, 根治をめざし放射線治療 を追加した。

予後は，他の部位の悪性リンパ腫より比較的良好とい われている.これは, 嗄声などの自覚的症状が早くから 出現しやすく, 早期発見が可能なこと, また, 甲状軟骨 に囲まれていることにより周囲から比較的隔離されてい ることなども一因 ${ }^{18)}$ と思われる. しかし，Gregor ${ }^{3)}$ は， 悪性リンパ腫の中には喉頭を含めて急速に全身に播種す る, 非常に予後不良の型があることを指摘しておゔ，本 邦の喉頭悪性リンパ腫の症例でもコバルト照射後 2 カ月 足らずで全身転移をきたし死亡した例32)が報告されて いる. Anderson ら ${ }^{1)}$ は長期間の経過観察のらちに遠隔 部位に再発した症例を報告しており，予後については必 ずしも楽観できず，長期間にわたる厳重な経過観察が必 要と思われる. 本症例について子，退院後 1 年 8 力月と 観察期間が短く, 今後も当院内科と協力しながらの経過 観察を予定している.

$$
\text { まとめ }
$$

55歳男性で，咽喉頭異常感にて受診した，喉頭右披裂 部原発と思われる悪性リンパ腫の症例について報告した。

1) 組織生検は，できるだけ挫隇をきたさず，より大 きな組織片を採取する必要がある。それにより，早期䛦 断, 早期治療につながる.

2 ）化学療法と放射線治療の併用療法により, 腫瘍が
消失し，現在良好な経過をたどっている。

稿を終えるに当たり，御校閲，御指導頂いた岡山大学医学部 耳鼻咽喉科学教室, 増田 游教授に深謝致します。

\section{参考文献}

1) Anderson HA, Maisel RH and Cantrell RW : Isolated laryngeal lymphoma. Laryngoscope $86: 1251 \sim 1257,1976$.

2 ) 岡部剛二 : 喉頭細網肉腫ノ一例. 大日耳鼻 $48: 820,1942$.

3 ) Gregor RT : Laryngeal malignant lymphoma ; an entity? J Laryngol Otol $95: 81 \sim 94,1981$.

4 ) Dessant LW and Weiland LH : Malignant lymphoma of the larynx. Laryngoscope $80: 966 \sim 978,1970$.

5 ）卜部信行, 横山道明, 杉原三郎, 他 : 喉頭に発生した悪性 リンパ腫. 耳喉 $54: 119 \sim 123,1982$.

6 ）堤昭一郎, 佐藤英光, 湯本英二, 他 : 喉頭に原発した悪性 リンパ腫の一症例. 耳喉 $58: 591 \sim 596,1986$.

7 ) Harris NL, Jaffe ES, Stein H, et al : A revised EuropianAmerican classification of lymphoid neoplasm ; a proposal from the international lymphoma study group. Blood 84 : 1361 1392, 1994.

8 ）古謝将宏, 又吉重光, 源河朝博, 他 : 喉頭悪性リンパ腫を 疑われた 1 症例. 日耳鼻 $83: 992,1980$.

9 ) 大野政一, 橋本真実, 山本 誠: 喉頭悪性腫瘍の特殊例の 2 例. 日耳鼻 $83: 1114,1980$.

10）都川紀正, 井上鐵三, 平出文久, 他 : 咽頭, 喉頭に発生し た悪性リンパ腫の 1 例. 日耳鼻 $83: 1671 \sim 1672,1980$.

11）富樫孝一, 田中久夫, 佐藤 充, 他: 喉頭に限局した悪性 リンパ腫の 1 症例. 頭頸部腫瘍 $9: 124,1983$.

12）堤内邦彦, 谷川 譲, 宮下久夫, 他: 声門下に限局した悪 性リンパ腫の 1 例. 日気食会報 $35: 192,1984$.

13）大八木章博, 松本 健, 二瓶誠五, 他 : 喉頭に原発した悪 性リンパ腫の 2 症例. 耳鼻臨床 $78: 2242,1985$.

14）稲光まゆみ, 中島格, 上村卓也, 他: 喉頭に発生した Polymorphic Reticulosis 一その免疫組織学的検討一. 日 気食会報 $40: 61 \sim 66,1989$.

15）奥村雅史, 山本博史, 牧本一男 : 喉頭覀性リンパ腫の 1 症 例. 耳鼻臨床 補35:33, 1990.

16）太根洋史, 米川紘子, 木村裕毅, 他 : 喉頭悪性リンパ腫の 1 症例. 日耳鼻 $93: 977,1990$.

17）小倉広之, 渡辺健二, 山本新作 : 喉頭悪性リンパ腫の 1 例. 日耳鼻 $93: 1135,1990$.

18）増田成夫, 内田正興, 川端一嘉 : 喉頭原発悪性リンパ盾の 一例. 耳喉頭頸 $62: 45 \sim 49,1990$.

19）加島健司, 三木 茂, 布村新作 : 喉頭にみられた悪性リン 八腫の 1 例. 日耳鼻 $93: 669,1990$.

20）石山哲也：喉頭悪性リンパ腫の一症例. 耳鼻臨床 補38： 
$135 \sim 138,1990$.

21）松田十四, 高木一平, 伊藤靖浩, 他 : 耳下腺, 喉頭披裂部 に原発したまれな節外性悪性リンパ腫の 1 例. 日耳鼻 93 : 1271, 1990.

22）酒井 昇, 本間明宏, 犬山征夫, 他: 小児の喉頭に発生し た悪性リンパ腫症例. 日気食会報 $42: 255 \sim 258,1991$.

23）青地克也, 松原一七, 西川邦男, 他 : 喉頭に発生した悪性 リンパ腫の 2 例. 耳喉頭頸 $63: 693 \sim 696,1991$.

24）宇野芳史, 斉藤龍介, 松岡寿子, 他: 喉頭に発生した稀な 悪性腫瘍の 3 症例. 耳鼻臨床 $85: 135 \sim 138,1992$.

25）石村 隆, 斉藤公基, 菅野陽子, 他 : 喉頭に原発し筋, 皮 膚, 腸管への浸潤を示したT細胞性リンパ腫の 1 例. 臨床 血液 $33: 1491,1992$.

26）山形和彦, 湯本英二, 兵頭正光, 他 : 喉頭悪性リンパ腫の 1 例. 耳鼻臨床 補58: 55 56, 1992.

27）永橋立望, 酒井 昇, 福田 諭, 他: 喉頭に発生した悪性 リンパ腫の四症例. 日気食会報 $43: 208,1992$.
28）寺田寿美子, 角田玲子, 西嶌 渡, 他 : 喉頭悪性リンパ腫 の一症例. 日気食会報 $45: 197,1994$.

29）菅家 稔：呼吸困難を主訴とした悪性リンパ腫の 1 例. 日 気食会報 $45: 197 \sim 198,1994$.

30）平尾元康, 原㴊保明, 朝倉光司, 他: 喉頭原発悪性リンパ 腫の 1 症例. 耳鼻臨床 補84: 178 183, 1995.

31) Connors JM, Klimo $P$, Fairey $R N$, et al : Brief chemotherapy and involved field radiation therapy for limited-stage, histologically aggresive lymphoma. Ann Intern Med $107: 25,1987$.

32）井土ふさ, 若林致雇, 新山宏二 : 喉頭細網肉腫剖検例. 日 耳鼻 $75: 1495,1972$.

$$
\left(\begin{array}{l}
\text { 原稿受付: 平成 } 7 \text { 年 } 11 \text { 月 } 16 \text { 日 } \\
\text { 原稿採択 : 平成 } 8 \text { 年 } 5 \text { 月 } 7 \text { 日 } \\
\text { 別刷請求先 : 瓦井博子 } \\
\text { †700 岡山市鹿田町 } 2-5-1 \\
\text { 岡山大学医学部耳鼻咽䐅科学教室 }
\end{array}\right)
$$

